\title{
TRANSNATIONAL TRADE TRANSACTIONS OF A FOREIGN STATE AND SOVEREIGN IMMUNITY IN INDIA: AN APPRAISAL
}

\section{K.I. Vibhute*}

\section{INTRODUCTION}

Commercial activities of States have extensively increased in contemporary international trade and commerce. Questioning and doubting the propriety of the notion of sovereign immunity, which originated from the maxim par in parem non habet imperium and is premised on the principles of independence and of sovereign equality and dignity, States have been distinguishing "governmental" or "public" acts (acta jure imperii) from those of a "nongovernmental" or "private" or "commercial" (acta jure gestionis) character in order to restrict absolute sovereign immunity. They accord immunity to a State only for its acts jure imperii and not for acts jure gestionis. This (restrictive) theory is ostensibly based on the premise that when a State, through its government-department or any other instrumentality, undertakes commercial transactions (with transnational effects) with a foreign firm or corporation, it is not entitled to immunity from the jurisdiction of other States for such transactions as that jurisdiction does not involve either a challenge or a threat to the dignity of the State concerned nor interferes with its sovereign functions.

A careful glance at the national immunity laws, the practice of States and international instruments on sovereign immunity ${ }^{1}$ unmistakably reveals that almost all States, except socialist ones, recognise the restrictive theory of

\footnotetext{
* Reader in Law, Post-Graduate Department of Law, University of Poona, Pune 411007 (India). 1 For national laws, see United Nations, Materials on Jurisdictional Immunities of States and their Property (ST/Leg./Ser.B/20[1982], hereinafter referred to as UN Materials on Immunities), and for state practice, see the State reports compiled in 10 NYIL (1979).
}

Asian Yearbook of International Law, Volume 3 (Ko Swan Sik et al., eds.; 0-7923-2708-X; (C) 1994 Kluwer Academic Publishers; printed in Great Britain), pp. 47-69 
immunity. However, perusal of the Indian laws governing immunity of a foreign State involved in commercial activities does not unequivocally exhibit a similar trend. Compared to national and international instruments on sovereign immunity it demonstrates a fragmentary approach to State immunity and discloses a few pertinent drawbacks.

This article attempts to evaluate the Indian law on State immunity for commercial transactions of a foreign State. A few suggestions are thereby offered to bring it on a par with the international instruments and other immunity laws in vogue.

\section{JURISDICTIONAL IMMUNITY OF A FOREIGN STATE IN INDIA: LEGAL FRAMEWORK}

Unlike the USA, the UK and other common law countries, India does not have a comprehensive legislation on jurisdictional immunity of a foreign State. However, the Code of Civil Procedure of 1908 (hereinafter referred to as "CPC") incorporates a chapter entitled "Suits by Aliens by or against Foreign Rulers, Ambassadors and Envoys". It deals, inter alia, with suits against a foreign State in India.

Section 86(1) of the CPC stipulates that no foreign State, ${ }^{2}$ Ruler of a foreign State, ${ }^{3}$ Ambassador or Envoy of a foreign State, High Commissioner of a Commonwealth country or any member of the staff or retinue of the Ruler, Ambassador or Envoy of a foreign State or of the High Commissioner of a Commonwealth country as specified by the Central Government, be sued in a competent court except with the consent of the Central Government in writing by a Secretary to the Government. Clause (2) of section 86 further directs the Central Government not to accord its consent unless it appears to it that the foreign State:

(a) has instituted a suit in the court against the person desiring to sue it, or

(b) by itself or another trades within the jurisdiction of the court, or

(c) is in possession of immoveable property situated within such jurisdiction

2 "Foreign State" has been defined to mean "any State outside India which has been recognized by the Central Government" (section 87A(1)(a) of the CPC). By virtue of s 87A(2)(a) a Court in India has to take judicial notice of the fact whether a State has or has not been recognized by the Central Government. De facto or de jure recognition has the same effect and the court before which a suit is filed has to obtain necessary information pertaining to recognition of the foreign State from the Government of India and information supplied by the government is conclusive on the matter. (See German Democratic Republic v Dynamic Industrial Undertaking Ltd, A.I.R. 1972 Bom. 27).

3 "Ruler", in relation to a foreign State, has been defined to mean "the person who is for the time being recognized by the Central Government to be the head of that State (section 87A(1)(b) of the CPC). And a court has to take judicial notice of the fact that whether a person has or has not been recognized by the central government to be the head of a State (section $87 A(2)(b)$ of the CPC). 
and it is to be sued with reference to such property or for money charged thereon, or

(d) has expressly or implicitly waived the privilege accorded to it by section 86(1) of the CPC.

Section 86 of the CPC, being lex fori, binds the courts in India in matters pertaining to the jurisdictional immunity of foreign States. A foreign State, therefore, cannot rely on the doctrine of sovereign immunity under international law and rules relating thereto when the Central Government has given its consent to the filing of a suit in India against such foreign State. In Mirza Ali Akbar v. United Arab Republic ${ }^{4}$ the Calcutta High Court was called upon to decide, inter alia, whether a foreign State engaged in commercial activities is entitled to absolute jurisdictional immunity in India. The foreign State argued that, according to the accepted general rules of (private) international law and in view of the difficulty of distinguishing acts jure gestionis from acts jure imperii, it was entitled to absolute immunity even in matters of a commercial nature. Justice A.N. RAY, favouring the sovereign and non-sovereign categorization of State activities for jurisdictional immunity purposes and relying heavily upon LAUTERPACHT, ${ }^{5}$ negatived the plea of absolute immunity and held that a State engaged in commercial transactions is not entitled to jurisdictional immunity in India. ${ }^{6}$ However, this rejection of the theory of absolute immunity received a setback when Chief Justice LAHIRI, speaking for the Division Bench of the High Court, relied upon the maxim par in parem non habet imperium, reversed the judgment, ${ }^{7}$ and concluded:

“...

... [N]o analogy can be drawn between the immunity of the domestic state and the immunity of an independent foreign state, because the essence of independence is freedom from the laws of every other country except one's own. The doctrine of restricted immunity based on the distinction between jure imperii and jure gestionis which rests on such insecure foundation cannot be accepted as the positive international law of our country."8

The Supreme Court of India, before which the matter finally went in appeal, ${ }^{9}$ reversed the judgment of the Division Bench by holding, inter alia, that section 86 CPC excludes the application of international law by the courts in India

4 A.I.R. 1960 Cal. 768.

5 H. LAUTERPACHT, "The problem of jurisdictional immunities of foreign States", 28 BYIL (1951) 220.

6 Supra n. 4 at p. 775.

7 United Arab Republic v. Mirza Ali [Akbar], A.I.R. 1962 Cal. 387.

8 Ibid, at 394.

9 [Mirza] Ali Akbar v. United Arab Republic, A.I.R. 1966 S.C. 230. 
and exclusively and conclusively determines the competency of suits against foreign States. The court, expressing the view that section 86 , to a certain extent, "modifies" the doctrine of immunity recognized by international law, observed:

“...

... [F]oreign States can be sued within the municipal courts of India with the consent of the Central Government and when such consent of the Central Government is granted as required by section 86(1), it would not be open to a foreign State to rely on the doctrine of immunity under international law, because the municipal courts in India would be bound by the statutory provisions, such as those contained in the Code of C.P. ... It is common ground that if there is a specific statutory provision, such as is contained in section 86(1) which allows a suit to be filed against a foreign State subject to certain conditions, it is the said statutory provisions that will govern the decision of the question as to whether the suit has been properly filed or not. In dealing with such a question, it is unnecessary to travel beyond the provisions of the statute because the statute determines the competence of the suit."10

The Ali Akbar case, in ultimate analysis, thus perceives that the provisions of section 86 CPC supplant international rules governing sovereign immunity, and mandates that a foreign State is precluded from invoking these rules in India once the Government of India consents to a suit against it.

However, the view has been expressed by the Bombay High Court that the word "modified" appearing in the Ali Akbar case signifies that the doctrine of immunity (along with the relevant principles relating thereto) in international law, is applicable in India though subject to the modification made in section 86. According to the Court, the modification effected by section 86 is the requisite consent of the Central Government and, to this extent, it operates as an additional exception to the doctrine of sovereign immunity in India. The Bombay Court accordingly refused to read that Ali Akbar implies that section 86 CPC "wholly supplants" the relevant doctrine of sovereign immunity under international law. ${ }^{11}$ Referring to the view taken in Royal Nepal Airlines Corporation v Manorama ${ }^{12}$ that sections 86 and 87 of the CPC have no relation to the principles of private international law and that these provisions of the Code afford additional protection or privilege to a foreign Sovereign by providing immunity from being sued in India without previous permission of the Central Government, the court further opined that section 86, requiring

$10 \mathrm{Ibid}$, at pp. 236-237.

11 German Democratic Republic v. Dynamic Industrial Undertaking Ltd, A.I.R. 1972 Bom. 27(4243).

12 A.I.R. 1966 Cal. 319 (329). 
consent of the Central Government, constitutes an exception to the principles of international law. ${ }^{13}$

Recently, a Division Bench of the Calcutta High Court has expressed its agreement with the viewpoint of the Bombay High Court that section 86 allows application of the principles of international law in India but expressed its inability to accept that the provision constitutes an exception to the principles of sovereign immunity operating in international law. ${ }^{14}$

In the light of the Ali Akbar decision of the Supreme Court it is submitted that the interpretation of the case as offered by the Bombay High Court, with which the Calcutta High Court concurs, seems unconvincing and in direct conflict with Ali Akbar. Section 86 of the CPC, as interpreted and perceived by the Supreme Court codifies the law relating to jurisdictional immunity of foreign States in India and thereby ousts the application of international law rules governing immunity of a foreign State in the Indian courts. It lists the circumstances in which a foreign State may be sued in India and thereby defines the bounds of jurisdictional immunity of a foreign State in India. In this sense, according to the Supreme Court, it "modifies" the doctrine of immunity as recognized in international law. Such an approach becomes clear when the Supreme Court states that section 86(1) "imposes liability", circumscribed and safeguarded by the limitations prescribed by it, "on foreign States to be sued" in India. Similarly, the viewpoint of the Bombay High Court, according to which the provisions of section 86 constitute an exception to the principles of international law governing sovereign immunity in India, seems to be at odds with the true legal effect of the section as dilated by the Supreme Court and reflects a highly artificial approach to statutory construction.

Interestingly, neither the Bombay High Court, in carving out the exception, nor the Calcutta High Court, in expressing its partial disagreement with the Bombay High Court, have given reasons for their respective views. A commentator rightly felt that the Bombay High Court judgment had proceeded on a misapprehension of the true legal effects of section 86 as interpreted by the Supreme Court and that the High Court had erred by equating the right of a foreign State to waive its privilege with the jurisdictional authority of the Government of India to give or refuse its consent for a suit against the foreign state. The learned commentator rightly opined that these two powers operate on different bases and have two different effects. ${ }^{15}$

The Ali Akbar ruling of the Supreme Court thus reflects the present law dealing with the doctrine of sovereign immunity in India. Section 86 of the

13 Supra n. 11, at p. 42.

14 New Central Jute Mills Co Ltd v. VEB Deutfracht Seereederei Rostock, A.I.R. 1983 Cal. 225 (234).

15 C.G. RaghavaN, "Sovereign Immunity in the Conflict of Laws-Some Recent Trends", IYIA (1980) 160. 
CPC, as it stands today, not only "supplants" the relevant principles of international law governing sovereign immunity and "controls" the doctrine of immunity in India, but also determines the competence of a suit against a foreign State in India. It, therefore, allows courts in India only to decide on the competency of a suit against a foreign State and not to deal with, and adjudicate upon, the contested claims of sovereign immunity on the basis of evidence adduced before them. A court in India can only dwell upon the question as to whether the requisite consent of the Government of India, prior to the suit, was obtained or not. Even the words "unless it appears to the Central Government", appearing in sub-section (2) of section 86 have been interpreted to the effect that the decision granting the consent is final on the question whether any of the clauses (a) to (d) thereof is satisfied and it is not open to a court to question the propriety of an order granting or refusing the consent. ${ }^{16}$

It is worth noting that neither the CPC nor any other legal instrument provides for procedures to be followed by the Central Government in exercising its decisional powers under section 86 and in case of an appeal from its order granting or refusing the requisite sanction. A set of interesting questions emerge out of these propositions, such as: is the Central Government vested with unbridled discretion to grant or refuse sanction for instituting a suit against a foreign State? If not, what are the requirements that may be legally asserted and/or ought to be considered by the Central Government in granting or refusing sanction? Is the Central Government empowered to adjudicate upon the merits of the claim(s) intended to be made by a petitioner(s) against a foreign State and thereby thwart legitimate claim(s) of the petitioner(s) by executive fiat? Is an order refusing or granting sanction beyond judicial scrutiny and, therefore, not justiciable? If so, does it even exclude judicial review of an erroneous, or malafide decision of the Central Government? Does section 86(2), expressly or by necessary implication, preclude a court to entertain the plea that the consent has been refused in violation of the provisions embodied in its clauses (a) to (d) and not in good faith? Answers to these allied questions will have to be attempted in light of the provisions of

(a) section 86(1) conferring an exclusive competence on the Central Government to allow a suit against a foreign State and

(b) section 86(2) enumerating a few guidelines for the Central Government, as well as

(c) section $86(6)$ on providing a reasonable opportunity for the person making the request to be heard before refusing to accede to his request.

The phraseology of section $86(2)$ as mentioned earlier unequivocally indicates that the Central Government, before it accords its consent, has to

16 See Govindram v. State of Gondal, A.I.R. 1950 P.C. 99; Mohamad Raza v. Kapurthala Estate, A.I.R. 1935 Ori. 164. For recent developments see infra. 
convince itself that the foreign State has instituted a suit against the plaintiff, or that it "trades" within the jurisdiction of the court, or that it possesses immoveable property within the jurisdiction of the court and that the intended suit deals with that property, or that it has, expressly or impliedly, waived the privilege accorded to it by section $86(1)$. The possibility of a decision in violation of these statutory guidelines or a decision motivated by some irrelevant, improper considerations or wrong assessment of the above requirements cannot be ruled out. The underlying idea of section 86 is to save a foreign State from harassment which may be caused by a suit based on mischievous, false and frivolous claims. The provision not only enables the Government of India to avoid such harassment to a foreign State but also to verify the contended claim(s) of a petitioner on the touchstone of its political relations.

Again sub-section (6) of s 86 imposes a mandatory obligation on the Central Government to give a reasonable opportunity of being heard to the person making the request before it refuses to accede to the request. It reads:

“...

(6) Where a request is made to the Central Government for the grant of any consent referred to in sub-section (1), the Central Government shall, before refusing to accede to the request in whole or in part give to the person making the request a reasonable opportunity of being heard." (emphasis supplied)

Though the sub-section embodies the principle of natural justice and attempts to do justice to the claim(s) of a petitioner, it does not encompass one of the well-accepted, important facets of the principles of natural justice, namely, a speaking order requiring the government to assign reasons for withholding its consent to the intended lawsuit against the foreign State. In fact, during the debate in the Lok Sabha on the insertion of section 86(2), a proviso requiring the Central Government to assign reasons, in writing, for disallowing a suit against a foreign State was unsuccessfully moved. Dr. V.A. SEYID MUHOMMAD, the then Minister of State in the Ministry of Law, Justice and Company Affairs who moved the Bill in the Lok Sabha, rejected the suggested amendment. His contention was that:

“... the very necessity for such a provision is that in certain cases where foreign States are involved, it may not be possible for the Central Government to give reasons why the consent is given or not given. To make it compulsory that in every case that reasons should be given defeats the very purpose of the provision." 17

17 Lok Sabha Debates (Fifth series), Seventeenth Session, vol. LXIII No.1. cols. 161-162 (12 August, 1976). 
It is submitted that from the point of view of a person seeking the requisite consent of the Central Government to sue a foreign State the above quoted justification for rejecting the suggested proviso does not hold water in the contemporary administrative age and appears unconvincing. It is important to recall that section 86 enables the Central Government to disallow frivolous claims against foreign States and thereby avoid their harassment in India. Contrary to the claim of the Minister, it is difficult to concede that a speaking order defeats the "very purpose" of section 86 . On the contrary, it is submitted, it would convince both the petitioner and the foreign State that their respective claims are objectively assessed and considered. The need and importance of the suggested "speaking order" or "reasoned decision" can be felt when one visualises the absence of any stipulated procedure in the CPC and envisages an indubitable wide jurisdiction and authority of the Central Government to give its sanction to sue a foreign State in India.

Endorsing such indubitable discretion, jurisdiction and authority of the Central Government in granting or refusing sanction under section 86, the Supreme Court recently observed in Harbhajan Singh v. Union of India ${ }^{18}$ :

“...

[T] he power given to the Central Government must not be exercised arbitrarily, or on whimsical grounds but upon proper reasons and grounds. ... [T]he Central Government is not to adjudicate upon the correctness of the claim.... [T] he power conferred on the Central Government ... shall be carefully exercised.... The power given to the Central Government must be exercised in accordance with the principles of natural justice and in consonance with the principle that reasons must appear from the order."19

The Court further rightly insisted that: “...

it is necessary that there should be an objective evaluation and examination by the appropriate authority of relevant and material factors in exercising its jurisdiction under section 86 by the Central Government. There is an implicit requirement of observance of the principles of natural justice and also the implicit requirement that decision must be expressed in such a manner that reasons can be spelled out from such decision. ... If the administrative authorities are enjoined to decide the rights of the parties, it is essential that such administrative authority should accord fair and proper hearing to the person to be affected by the order and given sufficiently clear and explicit reasons. Such reasons must be on relevant material

18 A.I.R. 1987 S.C. 9.

19 Ibid, p. 14. 
factors objectively considered. There is no claim of any privilege that disclosure of reasons would undermine the political or national interest of the country."20

The Supreme Court, in its quest to ensure "just" and "speaking order" from the Central Government in exercise of its powers under section 86 of the CPC, also tendered a bit of advice to the Central Government to accord its consent normally unless there are cogent political and other reasons. ${ }^{21}$

The apex Court of the land has also given sufficient indication that it is not the function of the Central Government to adjudicate administratively upon the merits of the claim(s) intended to be made by the litigants in their proposed suits against the foreign State and to determine the propriety of a claim before granting consent to the institution of a suit. According to the Supreme Court, it is the function of a competent civil Court to do so and the Central Government, therefore, cannot under section 86 , assume that jurisdiction. ${ }^{22}$

There are strong indications in the Harbhajan and other Supreme Court rulings $^{23}$ that not only is the decisional power of the Central Government subjected to the two above-mentioned limitations but its order is also subject to judicial scrutiny. The Central Government, through proper writ, can be directed to reconsider its "order" in the light of contemporary trends and developments of international law. The courts can go into the propriety of such orders by probing into the observance or non-observance of the principles of natural justice, absence of speaking order and adequacy of the stated reasons, administrative adjudication of the proposed suit by the Central Government before giving/refusing sanction, etc. It is worth noting that recently the Delhi High Court ${ }^{24}$ has gone one step further by directing the Central Government to accord its sanction within two months from the date of order in the light of the law laid down by the Supreme Court and international law.

It is interesting to note, however, that while the Supreme Court endorsed the decisional authority of the Central Government-obviously subject to the above mentioned limitations-and admitted that it (the Supreme Court) was "not concerned with the correctness or genuineness or otherwise" of such claim, its real concern lay in whether the grievances of the persons intending to sue a foreign State would be properly and legally dealt with. ${ }^{25}$ Accordingly the Supreme Court insisted on a fair, just, careful and objective exercise of the

20 Ibid, p. 15.

21 Ibid, p. 14. See also Narottam Kishore v. Union of India, A.I.R. 1964 S.C. 1590; Tokendra Bir Singh v Secretary to the Government of India, A.I.R. 1964 S.C. 1663.

22 Supra n. 19. See also Tokendra Bir Singh v. Secretary to the Government of India, ibid; Century Twenty One (P) Ltd v. Union of India, A.I.R. 1987 Del. 124.

23 Tokendra Bir Singh v. Secretary to the Government of India, supra n. 21; Norottam Kishore v Union of India, supra n. 21.

24 Century Twenty One (P) Ltd v. Union of India, supra n. 22.

25 Harbhajan Singh v. Union of India, supra, n. 18 at p. 12. 
discretion on some cogent political and other relevant grounds, rather than on whimsical, vague and fanciful grounds and opined that the provisions of the CPC must be interpreted in consonance with the basic principles of the Indian Constitution. ${ }^{26}$ The Supreme Court also cautioned the Central Government not to deny sanction on "political grounds" and generally to desist from administrative adjudication of merits of claims of petitioners and thereby usurp the jurisdiction of the competent civil courts. According to the Supreme Court such a refusal in ultimate analysis puts a restriction on the rights of citizens to institute a suit against a foreign State in respect of injuries suffered by them and to seek redress for it. It, therefore, tendered a bit of judicial advice to the Central Government normally to accord consent, keeping in view recent trends and developments in international law, international trade and commerce, and international interdependence, except in cases where the claim appears to be patent, frivolous or vexatious, intending to harass the foreign State.

The Code of Civil Procedure also mandates that no decree against a foreign State be executed against property of any foreign State without consent of the Central Government in writing. Sub-section (3) of section 86 reads:

“(3) Except with the consent of the Central Government certified in writing by a Secretary to that Government, no decree shall be executed against the property of any foreign State."

This provision makes it clear that the consent of the Central Government is also necessary in execution proceedings against a foreign State. Further, subsection (3) indicates eloquently that the requisite consent of the Government of India allowing execution of a decree against any property of a foreign State is unqualified. This interpretation gets support from section 86(6), which mandates the Central Government to ensure a reasonable opportunity of being heard only to a person requesting the requisite consent to sue a foreign State, not to a person seeking consent to execute a decree duly obtained by the latter against a foreign State. The cumulative effect of sub-sections (1) and (3) is that the requisite consent of the Central Government for executing a decree against property of a foreign State in India is distinct from, and independent of, the consent of the Central Government for filing a suit against a foreign State. Therefore, reasonable opportunity of being heard afforded by section 86(6) of the CPC cannot be extended to persons seeking permission to execute a decree against the foreign State's property in India.

However, it may be noted that the Law Commission of India, in its 54th Report on the Code of Civil Procedure of 1908 which was used as a model by the Parliament when overhauling the CPC in 1976, had suggested that

26 Ibid, p. 14, 15. 
reasonable opportunity of being heard be extended to persons requesting consent of the Central Government for execution of a decree against a foreign State. The recommended clause was worded as follows:

"(b) Where a request is made to the Central Government for the grant of any consent under this section, the Central Government shall, before refusing to accept the request in whole or in part, give the person making the request a reasonable opportunity of being heard."27 (italics supplied)

The Parliament of India, for the reasons best known to itself, when approving clause (b), replaced the words "grant of any consent under this section" by "grant of any consent referred to in sub-section (1)", making the clause applicable only to the requisite consent to sue a foreign State and not to execution of a decree against a foreign State.

The provision has a direct bearing on transnational arbitration. Section 14 of the Indian Arbitration Act, 1940, being the lex fori, makes it obligatory to file an award in a competent court for further proceedings in order to get a decree in terms of the award. And by virtue of section 86(3) of the CPC consent of the Central Government to execute the decree (obtained in terms of the award resulting from the agreed arbitral tribunal) against property of a foreign State even when used for commercial purposes is required. Compared to the corresponding provisions in the American Foreign Sovereign Immunity Act, the British State Immunity Act and the contemporary rules of international law in the area of sovereign immunity vis-à-vis international commercial arbitration, the provisions of the CPC not only depict a fragmentary approach to the rules of sovereign immunity vis-à-vis transnational arbitration in India but are also unfavourable to the development of transnational arbitration in India.

From the foregoing analysis it is amply clear that section 86 , as interpreted by the Supreme Court in the Ali Akbar case, vests the Government of Indiaunlike its American and British counterparts-with the sole decisional authority in the determination of claims of sovereign immunity and courts in India, subject to the above-mentioned judicial inroads, play only a secondary role in the matters pertaining to sovereign immunity.

It is worth noting that in the USA, before the Tate Letter, the State Department dominated in determining sovereign immunity claims, and the courts, as in contemporary India, only played a secondary and supportive role. In 1976, realizing that the political organs of the State should not be allowed to adjudicate upon legal claims of sovereign immunity, the responsibility was transferred from the State Department to the courts through the FSIA. Section 1602 of the FSIA, declaring its purposes reads: 


\begin{abstract}
"The Congress finds that the determination by United States Courts of the claims of foreign States to immunity would serve the interests of justice and would protect the rights of both foreign States and litigants in United States courts. ... Claims of foreign States to immunity should henceforth be decided by courts of the United States in conformity with the principles set forth in this chapter."
\end{abstract}

Similarly, section 1(2) of the British SIA which, inter alia, sets provisions with respect to proceedings in the United Kingdom by or against other States and with respect to the immunities and privileges of heads of State, empowers a court to give effect to the jurisdictional immunity of a foreign State.

It needs no emphasis that determination of claims of sovereign immunity by courts, as aptly proclaimed in the FSIA, not only serves the interests of justice for which a civilised State strives, but also protects legitimate rights and claims of both foreign States and private individuals, one of the dominant and accepted claims of the Rule of Law doctrine. There are no convincing reasons for not shifting the decisional responsibility from Central Government to the courts in determination of sovereign immunity claims in India. The considerations, namely the interests of justice and the protection of rights and claims of a foreign State and a private individual, which have led the US Congress to entrust the US courts to decide matters relating to sovereign immunity, are equally relevant to, and applicable in, India. They warrant due consideration by the Indian legislature. In fact, as mentioned earlier, recent judicial pronouncements contain sufficient indication in this direction.

\title{
3. WAIVER OF IMMUNITY VIS- $\dot{A}$-VIS TRANSNATIONAL COMMER- CIAL ACTIVITY OF A FOREIGN STATE
}

It is a well-settled principle of sovereign immunity that the courts of a country cannot by their process make a foreign State a party to legal proceedings without its consent. Such a consent may be express or implied (the terms "express" and "implied" waiver of immunity are self-explanatory). Express waiver of immunity may be through an international agreement or a term contained in the contract or by express consent given before or after a dispute, while tacit consent to waive its immunity may be read in the acts of the foreign State indicating its willingness to submit either to the courts or arbitral tribunals.

Section 86(1) of the CPC, as discussed above, requires prior consent of the Central Government to sue a foreign State in India and section 86(2) makes it unequivocally clear that the Central Government, before according its sanction, has to satisfy itself whether the foreign State, according to its perception

(a) has already instituted a suit against the plaintiff; or

(b) trades, itself or through its agency; or 
(c) possesses an immoveable property which is subject-matter of the suit; or

(d) has expressly or impliedly waived its privilege.

The institution of a suit by a foreign State, matters arising out of possession of immoveable property in the possession of a foreign State and express waiver of immunity are questions of fact and can, therefore, be taken note of without much difficulty. The trading by a foreign State and the waiver of immunity, particularly implied waiver of immunity, on the other hand, are comparatively not so simple.

\subsection{Implied waiver of immunity}

Clauses (b) and (d) of section 86(2) warrant consent of the Central Government if a foreign State "trades", by itself or through another, or has "waived", expressly or impliedly, its privilege. But the Code neither defines nor explains these key phrases, nor does it provide any guidance for their determination. There is no indication either whether clauses (a) to (c) actually contain the modes of implied waiver of sovereign immunity recognized by the Code. If they do, it is submitted that clause (d), separately referring to "express or implied waiver" of the privilege accorded by section 86(1), is in fact redundant.

However, such interpretation seems odd and unwarranted in the light of the Mirza Ali Akbar case, wherein the Supreme Court has held that section 86 is a complete Code on sovereign immunity in India. Nor is it clear whether a suit against a foreign State which is involved in trade or which has expressly or impliedly waived its privilege, still requires the consent of the Central Government. It may be argued that a foreign State, even if it is involved in trading activities or has waived its privilege, can not be sued in India without prior permission of the Central Government by virtue of section 86 CPC. On the other hand, in the light of contemporary State practice and the principles of international law governing sovereign immunity one may advance a counterargument according to which a foreign State, by trading or waiving its privilege, is directly amenable to the courts and, therefore, can be sued without consent of the Central Government. In the absence of legislative policy both arguments seem equally sound and convincing in the context of their respective perceptions of the ambit of section 86 .

Against the background, and in the context of, accepted principles of international law pertaining to waiver of sovereign immunity, it is submitted that it would be wrong to equate the right of a foreign State to waive its privilege with the jurisdictional authority of the Central Government to accord or refuse consent in case of a request to file a suit against the foreign State. Waiver is governed by the will of the foreign State while granting or withholding consent refers to the decisional power of the Central Government. Section $86(2)$ (d) merely provides a situation in which as a result of waiver of sovereign immunity consent may be given and, therefore, does not deal with 
criteria for the determination of waiver of immunity nor with the circumstances amounting to such waiver.

In most other countries "trading" by a foreign State has been accepted as an exception to the doctrine of sovereign immunity by relying upon the restrictive theory of immunity based on the distinction between acta jure gestionis and acta jure imperii. Against this background it seems odd to insist on the consent of the Central Government for suing a foreign State which has undertaken commercial activities within the jurisdictional limits of a court. Unfortunately, the CPC is silent on these and similar issues.

After these preliminary observations pertaining to the nature and scope of section 86(2) with respect to implied waiver, let us now consider the guidelines enumerated in section 86(2).

\subsubsection{Implied waiver by submission to a court's jurisdiction}

Unlike in the UK, where a foreign State may enter a conditional appearance in a court of law to have the writ set aside, the law in India does not provide for such conditional appearance. Therefore, one of the crucial questions is when a foreign State can be said to have submitted to a Court's jurisdiction in India and thereby waived its immunity? In Mirza Akbar v. United Arab Republic $(U A R)^{28}$ it was argued before the Calcutta High Court, as a preliminary issue, that the UAR, by making appearance to a writ and asking for relief, had submitted to the jurisdiction of the court and thereby had waived its privilege. Justice A.N. RAY, the trial judge, accepting the argument, held that the UAR had submitted to the jurisdiction of the court and thereby waived its privilege. However, in appeal a Division Bench consisting of LAHIRI C.J. and BACHAWAT J., placing reliance on Mighell v. Sultan of Johore ${ }^{29}$ and In Re Bolivia Republic Exploration Syndicate Ltd, ${ }^{30}$ expressed its inability to accept the view of RAY J. as a correct proposition of the law and ruled that merely making an application challenging jurisdiction of a court does not amount either to submission to jurisdiction or waiver of jurisdictional immunity. ${ }^{31}$ The Court further stated that the appearance must be unconditional and unequivocal in order to qualify as submission to the jurisdiction of a court. Relying heavily upon the views of CHESHIRE, DICEY and some statements of law deduced by them, the Division Bench inferred that such appearance, in order to constitute waiver of sovereign immunity, must be an unmistakable election to submit to the court's jurisdiction and not mere unconditional

28 Supra n. 4.

29 (1894) 1 Q.B. 149.

30 (1914) 1 Ch. 139.

31 Supra n. 7. 
appearance of a foreign State. ${ }^{32}$ Again in Royal Nepal Airlines Corporation v. Manorama $^{33}$ it was pressed before a Division Bench of the Calcutta High Court comprising of BOSE C.J. and MITTER J. that the Royal Nepal Airlines Corporation, a corporate body of the Royal Nepal Government, had submitted to the jurisdiction of the court and thereby had waived its immunity by appearing in the court and by filing a written statement. The Division Bench, after analyzing the relevant English authorities and its earlier judicial pronouncements, concluded that there must be an unmistakable election to submit to the court's jurisdiction or a deliberate abandonment of the right to claim sovereign immunity from which an unequivocal intention to submit to jurisdiction could be inferred. The Court further held that such unequivocal intention and unmistakable election to submit to the court's jurisdiction must be by a person having the right to waive with the consent of the foreign sovereign. ${ }^{34}$ In Indian National Steamship Co Ltd v. Maux Faulbaum $^{35}$ the Calcutta High Court held that Indonesia, by its conduct, had waived its privilege to claim jurisdictional immunity when it applied for leave to be examined pro inter se sua and asked the court to investigate the question of its title of goods on board and applied for issue of Letters of Request to examine witnesses in Holland to prove its title.

\subsubsection{Implied waiver by trading in a foreign State}

Two questions deserve consideration: whether the word "trading" in section 86(2)(b) includes acta jure gestionis and thereby incorporates within its ambit the commercial activity exception to the sovereign immunity, and whether an agreement to submit a dispute to arbitration amounts to a submission to the jurisdiction of the court in India.

Clause (b) of section 86(2) allows the Central Government to accord its

32 Ibid, p. 390.

33 Supra n. 12.

34 Ibid, p. 331.

35 A.I.R. 1955 Cal. 491. For details and comments, see S.K. Agrawala, "The plea of sovereign immunity and Indian State practice", Revue Hellénique de droit international (1975) p. 20 et seq. In this case the Indonesian Purchasing Commission which is a department of the Defence Ministry of the Government of Indonesia purchased 51 reels of cable in Hamburg and shipped the said goods for carriage from Hamburg to Jakarta under a bill of lading. The vessel altered its course and at the direction of the owner company (the Indian National Steamship Co.) proceeded to Calcutta and there unloaded the entire cargo which was on board the vessel. The owner company filed a suit thereafter against Maux Faulbaum (the charterer of the said vessel) claiming certain sums alleged to be due to it on account of arrears of hire of the said vessel and claiming a lien on all goods on board the said vessel including the 51 reels of cable. The Calcutta High Court appointed a receiver for the entire cargo. The Indonesian Purchasing Commission, through the Republic of Indonesia, claiming a superior title to that of the receiver made an application to the court for possession of the goods. 
consent to a request to sue a foreign State if the latter, by itself or another, trades within the local limits of the court. To the knowledge of the writer no judicial pronouncement of an Indian court interpreting the term "trading" is reported as yet. However, the Memorandum on State Immunity in respect of commercial transactions, submitted by the Government of India to the AsianAfrican Legal Consultative Committee (AALCC) in 1960, ${ }^{36}$ reveals the viewpoint of the Government of India on commercial activities of a foreign State $v i s-\grave{a}$-vis its immunity. The Government of India in its Memorandum showed its preference to the restrictive immunity theory, premised on the distinction between acta jure gestionis and acta jure imperii. Addressing itself to the question as to whether a foreign State be immune from jurisdiction of the courts of a country with respect to "commercial" and other non-governmental activities and by reviewing pertinent State practice as existed at that time and referring to the opinions of international jurists, the Government of India asserted:

\begin{abstract}
"If it is decided to adopt a practice restricting the grant of immunity to foreign States in respect of their trading activities, no objection could legitimately be taken. Even on principle it appears that the time has now come when a distinction between the various forms of State activities for the purposes of immunity is desirable and indeed essential. The activities that are undertaken by modern States can not be regarded as State activities in the sense it was understood and it would indeed be stretching the point too far if the principle of sovereign immunity was applied to all such activities undertaken by a State today. If a sovereign State chooses to trade, it should be in no better position than an individual or company engaged in foreign trade. To allow immunity in such cases will result in unduly putting a sovereign State in a better position than a trading individual or a company for which preferential treatment there is no warranty in international law or usage. ... [ $[\mathrm{t}$ t may well be asserted that a State by taking upon itself the role of a trader must be deemed to have waived its claim of immunity in respect of such transactions." 37
\end{abstract}

The Indian delegate participating in the first session of the AALCC expressed his views on the matter. He also favoured the distinction between public and private activities of a State and opined that immunity should not be extended to commercial activities of States as in such ventures no question of dignity of sovereign States arises. According to him, if a State enters the area of trade activities it should be prepared, if the occasion so arises, to suffer the same processes of law as a citizen would be subjected to. He further opined that with States participating more and more in commercial activities it is desirable

36 For the text of the Memorandum see, Asian-African Legal Consultative Committee, Third Session, Colombo, 1960, issued by the Secretariat of the AALCC, New Delhi, India, pp. 58-62.

37 Ibid, p. 62.

38 New Delhi, 1957. 
that the immunity should not operate on non-governmental activities. ${ }^{39}$ The Indian delegate, responding to one of the questions posed by the AALCC, also expressed his willingness to adopt the doctrine of qualified immunity. ${ }^{40}$ The Government of India also agreed that the doctrine of sovereign immunity should not be applicable to commercial transactions undertaken by State trading organizations, and that no distinction could be drawn in principle between such activities undertaken directly by a government and those which are done through trading organizations, whether they constitute a separate juristic entity or not. Accordingly even trade representatives of a government should not be entitled to immunity. ${ }^{41}$

It is, thus, evident that the Indian assertion that immunity should be confined to "governmental" in contradistinction to "non-governmental" or "commercial" transactions of a foreign State and that a foreign State resorting to commercial activity should be deemed to have waived its claim of immunity revealed its faith in the widely accepted and practised theory of restrictive immunity. However, it is interesting and significant to note that the Government of India has not been influenced in its actual conduct by the restrictive view of immunity pursued and advocated in its Memorandum. In 1971 in Isbrandtsen Tankers Inc v. President of India, ${ }^{42}$ even in the face of an arbitration clause clearly amounting to a waiver of immunity, India successfully invoked immunity before foreign courts for its commercial activity.

The success and precision of the theory of limited immunity, as discussed above, ultimately depend upon certain specific criteria or tests selected for such a distinction. Unfortunately, the Memorandum, favouring and stressing the distinction and indicating its faith in the restrictive immunity theory, has not addressed itself to the crucial question as to the criteria for the determination of such "commercial activity" of a State. The Indian delegate missed a unique opportunity to formulate and develop certain criteria for distinguishing acta jure gestionis from acta jure imperii when he abstained from making suggestions in respect to a specific question on the point posed by the AALCC. The omission on the part of the Indian delegation to do so is regrettable and unfortunate for it was the Government of India that brought forward the subject of State immunities for discussion and recommendation by the AALCC.

39 Loc. cit. n. 36 pp. 63-64. The AALCC, accordingly, recommended that a State which enters into transactions of a commercial or private character ought not to raise the plea of sovereign immunity if sued in the courts of a foreign State in respect of such transactions and if the plea of immunity is raised it should not be admissible to deprive the jurisdiction of the domestic courts. Final Report of the Committee on Immunity of States in respect of Commercial and other Transactions of a Private Character, as revised in the third session of the AALCC, ibid p. 68.

40 Ibid, p. 72.

41 Ibid, pp. 67-68.

42 See 66 AJIL (1972) 396. 
The Government of India has not made any public declaration in pursuance of its policy of favourably inclining to the restrictive immunity theory and thereby disallowing immunity to a foreign State in respect to its commercial activities, but its preferences have, of course, to be appreciated against the background of the provisions of section 86(1) and (2) of the CPC.

\subsubsection{Implied waiver by agreement to arbitrate}

The Memorandum of the Government of India presented to the AALCC, which makes fleeting reference to the frequent insistence by traders entering into contracts with foreign States on the insertion of an arbitration clause and the voluntary submission of States to arbitration or jurisdiction of domestic courts, does not reveal any considered opinion of the Government of India on the question as to whether an arbitration agreement to submit disputes to arbitration amounts to submission to the jurisdiction of the courts in India. Neither the guidelines incorporated under section 86(2) CPC nor judicial pronouncements provide any indication, and in the absence of executive, legislative as well as judicial policy it is difficult to comprehend when and to what extent an arbitration clause is to be considered an "implicit" waiver of immunity in Indian law. As mentioned earlier, section $86(2)(d)$ provides a ground for the Central Government to consent to a foreign State being sued in India if that State has expressly or impliedly waived its privilege.

It is worth mentioning that section 1605(a)(1) of the US Foreign Sovereign Immunity Act, 1976, which is similar to section 86(2)(d) CPC, provides that a foreign State is not immune from the jurisdiction of US courts in any case

"in which the foreign State has waived its immunity either explicitly or by implication ..."

Like the Indian CPC, the American FSIA does not specifically prescribe that the presence of an arbitration clause in a contract amounts to implicit waiver of sovereign immunity. However, the legislative history of the FSIA sheds some light on the intent of the US Congress. The Congressional report gives a strong indication that a foreign State waives its immunity when it agrees to arbitrate in another country and presence of an arbitration clause in a contract ipso facto amounts to waiver of immunity. The report accompanying section 1605(a)(1) of the FSIA states:

“...

[W]ith respect to implicit waivers, the courts have found such waivers in cases where a foreign State has agreed to arbitration in another country or where a 
foreign State has agreed that the law of a particular country should govern a contract.",43

The congressional statement seeks support from cases decided prior to, ${ }^{44}$ and immediately after ${ }^{45}$ the introduction of the FSIA. However, it should be noted that only an agreement to arbitrate in the United States, and not in any foreign country, constitutes an implicit waiver of immunity from jurisdiction of the US courts. ${ }^{46}$

The State Immunity Act (SIA) 1978, of the United Kingdom, which regulates immunity of a foreign State in the UK and codifies the restrictive theory of sovereign immunity, also provides that an arbitration clause in a contract disentitles the foreign State for jurisdictional immunity. Section 9 of the SIA, dealing with the impact of an arbitration agreement on jurisdictional immunity, states, inter alia:

“...

(1) Where a State has agreed in writing to submit a dispute which has arisen, or may arise, to arbitration, the State is not immune as respects proceedings in the courts of the United Kingdom which relate to the arbitration."

Even in the pre-SIA period Lord DENNING M.R. had opined that: “...

Usually the contract contains an arbitration clause, in which case there is a

43 House Report No. 94-1487, 94th Cong. 2d Sess. 18 (1976). Reprinted in UN Materials on Immunities, supra n.1, p. 98 (109).

44 Wilmotte \& Co v. Rosenman Bros, 258 N.W. 2d 317 (Iowa, 1977); Victory Transport Inc. v. Comisoria General de Abastecimientosy Transportes, 232 F. Supp. 294 (S.D.N.Y. 1963); Victory Transport Inc. v. Comisoria de Abastecimientosy Transportes, 336 F. 2d 354 (2d Cir. 1964); Petrol Shipping Corp. v. Kingdom of Greece, 360 F. 2d 103, (2d Cir. 1966).

45 Ipitrade International SA v. Federal Republic of Nigeria, 465 F. Supp. 824 (D.D.C., 1978); LIAMCO v. Socialist People's Libyan Arab Jamahirya, 482 F. Supp. 1175 (D.D.C. 1980); MINE v. Republic of Guinea, 20 I.L.M. (1981) 669.

46 Verlinden BV v. Central Bank of Nigeria, 488 F. Supp. 1284 (S.D.N.Y. 1980); Chicago Bridge \& Iron Co v. Islamic Republic of Iran, 506 E. Supp. 981 (N.D.I.11, 1980); Ohntrup v. Firearms Centric Inc 516 F. Supp. 1281 (D.D.C. 1981); Zernicek v. Petroleos Mexicanos, 614 F. Supp. 407 (S.D. Tex. 1985). See also, Gary B. Sulliven "Implicit Waiver of Sovereign Immunity by Consent to Arbitration: Territorial Scope and Procedural Limits", 18 Tex. I.L.J. (1983) 329; KAHALE, "Arbitration and Choice-of-Law Clauses as Waivers of Jurisdictional Immunity', 14 N.Y.U.J.I.L. Pol. (1981) 29; KAHALE and VeGA, "Immunity and Jurisdiction: Towards a Uniform Body of Law in Actions against Foreign States", 18 Col.J.Tr.L. (1979) 211. 
voluntary submission to the jurisdiction of the arbitrators and the supervision of them by the courts." 47

Beside these provisions of the FSIA and the SIA international agreements, such as the European Convention on State Immunity (1972), ${ }^{48}$ the Draft Convention on State Immunity prepared by the International Law Association (1983) ${ }^{49}$ the Draft Articles on Jurisdictional Immunities of States and Their Property of the International Law Commission (1986) ${ }^{50}$ and recently enacted national legislation ${ }^{51}$ do concur that a foreign State, which is a party to an arbitration agreement, is precluded from asserting its immunity from the jurisdiction of the courts of the forum.

A comparison of these provisions with the circumstances listed in clauses (a) to (d) of section 86(2) CPC reveals the inadequacy of the provisions embodied in the Indian Code of Civil Procedure.

Meanwhile, it is significant to note that in Union of India v. Owners of Vessel Huegh Orchid \& their Agents, ${ }^{52}$ a case pertaining to stay of proceedings in respect of matters referred to arbitration under the Foreign Awards (Recognition and Enforcement) Act 1961, the Gujarat High Court, after a cursory analysis of the provisions of Article 14 of the New York Convention on the Recognition and Enforcement of Arbitral Awards 1958, refused to accede to the argument advanced by the Central Government that an arbitral clause in the charter party contract obliging it to make a reference to foreign arbitration amounts to a denial of its sovereign status and that such an agreement is valid and binding between citizens of different States only. ${ }^{53}$

\section{CONCLUSION}

Section 86 of the CPC as interpreted by the Supreme Court of India in Ali $A k b a r$, constitutes a complete Code on sovereign immunity of a foreign State in India and it is applicable to the exclusion of the principles of international law relating to sovereign immunity. However, subsequent to the Ali Akbar ruling the Bombay and Calcutta High Courts, by offering their own interpretation to the ratio of Ali Akbar and its implications, have expressed the view that the

47 Thai-Europe Tapioca Service Ltd v. Government of Pakistan, (1975) 1 W.L.R. 1485. See also, President of India v Metcalfe Shipping Co Ltd, (1970) 1 Q.B. 289.

48 Article 12.

49 Article III (A).

50 Article 11.

51 See generally, UN Materials on Immunities, supra n. 1, Part I, pp. 3-72, and the State reports compiled in 10 NYIL (1979).

52 A.I.R. 1983 Guj. 34.

53 Ibid, pp. 42-43., V 
provisions of section 86 do not supplant the relevant principles of international law and that they are still applicable in India subject to the modifications made in section 86.

Constitutionally, the ratio of Ali Akbar is not only binding on all courts within the territory of India but also stands as good law in the field until overruled by a larger Bench of the Supreme Court. Yet the judicial deliberations and contrary views of the high judicial forums regarding the true ambit and interpretation of section 86 CPC and the application of contemporary international law rules and principles on the subject depict a fundamentally different perception of the immunity in the Indian courts of foreign States engaged in commercial activities. Examined against the background of the prevailing statutory enactments and State practice in the UK, USA and other common law countries and the principles of contemporary international law it is in fact not clear whether the provisions of section 86 really embrace the theory of restrictive sovereign immunity based on a distinction between acta jure gestionis and acta jure imperii.

The provisions of section 86 vest the Central Government with the decisional authority to determine matters which involve claims of sovereign immunity. The courts in India are concerned with the competency of a suit against a foreign State and not with the question of sovereign immunity. They are not permitted to adjudicate upon a claim against a foreign State on the basis of evidence adduced before them, unless the Central Government has given its consent to the filing of the suit.

In view of the historical antecedents that led the US to transfer the decisional authority on claims of sovereign immunity from the State Department to the courts and in view of the underlying legislative policy according to which the political wing of the State should not be entrusted with the decisional responsibility in legal questions which can properly be resolved through ordinary judicial process, it is difficult to appreciate the sole decision-making authority vested in the Central Government of India. It is important to note that the Government of India, responding to one of the questions posed by the AALCC, has opined that the plea of immunity be left to the courts. In view of the extended function of a State, including commercial activities and its wide legal capacity to intervene, it is imperative for a system of law not only to accommodate legitimate interests of individuals doing business with foreign governments but also to empower them to assert the determination of their legitimate claims arising out of such transactions by courts on the basis of judicial reasoning rather than by a political agency of a State on political or other considerations. The Rule of Law and the need of justice for individuals in their transactions with a foreign State which has entered the market-place and which has acquired the character of a trader, warrant adjudication of such claims by courts. A foreign State should not be allowed to take shelter under the protective umbrella of sovereign immunity to deprive the private party of his legitimate claims arising out of the commercial activities simply on the 
ground that he has had privilege to trade with a foreign State and to suffer damage.

While section $8 \mathrm{~b}$ para. 2 enumerates a few situations, subject to which consent is to be given to a lawsuit against a foreign State, it is not clear whether the sub-section embodies the acta jure gestionis and other exceptions to jurisdictional immunity provided in the American FSIA and the British SIA. None of the conditions are explained or defined in the CPC, and compared to the similar exceptions to immunity provided in the FSIA, the SIA and the European Convention of 1972 the Indian provisions are vague and imprecise.

In the interest of justice for private individuals involved in commercial activities with a foreign State and in order to bring the Indian law on a par and in harmony with other contemporary systems of law and State practice, the present discretion of the Central Government is to be done away with at the earliest opportunity. It is high time to transfer the decisional responsibility from the Central Government to the courts and to reconsider the situations amounting to implied waiver of sovereign immunity in the light of prevailing State practice, overseas statutory instruments and international conventions. It is, therefore, suggested that a comprehensive legislation on sovereign immunity, like the FSIA, the British SIA and identical statutes operating in a number of common law countries, be enacted in India. The Supreme Court in the Ali Akbar case has endorsed the legislative competence of a State to enact such a law to govern rights and liabilities of a foreign State in India.

Undoubtedly, legislative moves in this direction need a careful analysis and an in-depth study of the legal instruments operative in different States and at the international level. It is submitted that pending the enactment of a comprehensive law the present section 86 of the CPC, be substituted by the following suggested clause:

86. No foreign State shall be immune from jurisdiction of a court in India when the foreign State:

(a) has submitted to the jurisdiction of the court, or

(b) has engaged in a commercial activity in India, or

(c) has expressly or impliedly waived its immunity.

Explanation: For the purpose of this section:

(1) "Foreign State" means any State outside India which has been recognized by the Central Government and includes a political sub-division of a foreign State or any agency or instrumentality of a foreign State.

An agency or instrumentality of a foreign State means any entity:

(i) which has a separate and distinct legal personality, corporate or otherwise, and

(ii) which is an organ of a foreign State or political sub-division thereof, or a majority of whose shares or other ownership interest is owned by a foreign State or political sub-division thereof. 
(2)(A) A foreign State is said to have submitted to the jurisdiction of the courts in India and thereby waived its immunity, either:

(i) by international agreement; or

(ii) by an express term contained in a contract in writing; or

(iii) by express consent given after a dispute between the parties has arisen; or

(iv) by a declaration before the court in a specific case.

(B) A foreign State be deemed to have submitted to the jurisdiction of the courts in India if:

(i) it has instituted a suit in the court against the person desiring to sue it; or

(ii) it has intervened or taken any step in the proceedings in India except to claim immunity or to protect its interests in the property in which it would have been entitled to immunity if the proceedings have been brought against it; or (iii) it is in possession of immoveable property situated within local limits of the jurisdiction of the court and it is to be sued with reference to such property or for money charged thereof; or

(iv) it has made any counter-claim in proceedings before the court; or

(v) it has agreed in writing to submit a dispute, present or future, to arbitration (such submission be applicable only to proceedings relating to the arbitrations).

(3) "Commercial activity" means:

(i) any contract for the supply of goods or services;

(ii) any loan or other transaction for the provision of finance and any guarantee or indemnity in respect of such transaction or any other financial obligation; and

(iii) any other transaction or activity (whether of a commercial, industrial, financial or other similar character) into which a State enters or in which it engages otherwise than in the exercise of sovereign authority.

Such acts may be either a regular course of commercial conduct or a particular commercial transaction or act." 